\title{
Ground Water Arsenic Poisoning in "Tilak Rai Ka Hatta” Village of Buxar District, Bihar, India Causing Severe Health Hazards and Hormonal Imbalance
}

\author{
Kumar A*, Ali Md, Rahman S Md, lqubal A Md, Anand G, Niraj PK, Shankar P and Kumar R
}

Mahavir Cancer Institute and Research Centre, Patna, Bihar, India

\begin{abstract}
In the recent times, arsenic poisoning due to contaminated ground water in the middle Gangetic plain has resulted to lots of health related problems in the population. In Bihar (India), about 16 districts have been reported to be affected with arsenic poisoning. In the present study, Tilak Rai Ka Hatta village, a flood plain Diara region of river Ganga in Buxar district was targeted for the ground water arsenic assessment and health related problems assessments among the village population. Altogether, 120 water samples were randomly collected for arsenic estimation and their results were statistically analysed. While for assessment of health related problems in the village people, 120 biological samples (blood) were collected from the same households. The study showed high contamination of arsenic in the ground water as three fourth region of the entire village had arsenic levels more than $100 \mathrm{ppb}$. The typical symptoms of hyperkeratosis in the palm and sole, melanosis of the skin in the village people were highly prevalent. In the population, there was prevalence of cancer and infertility cases also. The assessment of blood samples exhibited severe hormonal imbalance among the village population. Present study thus concludes that, arsenic poisoning in entire village has caused severe health hazards to the village population. It has not only caused skin diseases or cancer but the entire population has threat over the infertility due to hormonal imbalance. So, a proper strategy is immediately required to cater the severity of the arsenic poisoning in this village.
\end{abstract}

Keywords: Arsenic poisoning; Tilak Rai Ka Hatta village; Buxar district; Ground water; Health assessment; Hormonal imbalance

\section{Introduction}

In the recent times, the potable water demand in urban as well as rural areas has increased a lot due to fast growing population in India. The Upper, Middle and Lower Ganga flood plains are the most severely dense populated areas of India. The entire land area is highly fertile and agricultural practices are the main occupation of the village people. The primary states of the upper, middle and lower Ganga plains are Uttrakhand, Uttar Pradesh, Bihar and West Bengal. The upper Ganga plain areas are from the states of Uttrakhand and Uttar Pradesh; middle Ganga plain areas are from the Eastern Uttar Pradesh and Bihar state, while the lower Ganga plain covers the entire West Bengal state [1]. The present study area is located in Buxar district which is south to the Middle Ganga plains and these areas are densely populated since the pre-historic times because of its religious importance as well as the highly fertile agricultural land.

Arsenic is abundant in the crust of the earth and is found in all environments. It is found in soil, minerals, surface and groundwater. Both natural and anthropogenic sources are responsible for the distribution of it throughout the environment [2]. The excessive withdrawal of ground water for agricultural practices was well practiced in 1990's which lead to geological changes in Gangetic plain. This lead to the lowering down of the water table in summer season and oxygen to enter into the aquifer causing oxidation of arsenic rich iron sulphide and then contaminating the entire aquifer with arsenic [3-5].

Today, it is estimated that more than 5 million people in the Bihar state are drinking water with arsenic concentrations greater than $50 \mu \mathrm{g} / \mathrm{l}[6]$ and presently the ground water arsenic contamination has spread to 16 districts of the state [6-9]. In India, problems with arsenic in groundwater in West Bengal (Lower Ganga plain region) were first recognised in the early 1980s and the health effects are now reasonably well documented $[1,10,11]$. Due to groundwater arsenic contamination, a large number of populations in the arsenic hit area are suffering from melanosis, leuco-melanosis, keratosis, hyperkeratosis, dorsum, non-petting oedema, gangrene, skin cancer and skin lesions in sole and palm [12-16]. Tubewell revolution since 1980's, has led to serious arsenic menace causing severe health hazards in the population in the recent years $[17,18]$. The village people of these contaminated regions are still drinking arsenic contaminated water and are not aware of this fact as well as its consequences. The demographic evaluation of arsenic in the ground water has not been done extensively especially in the Buxar district where arsenic poisoning in ground water has a meagre reporting.

The Buxar district is situated between $25^{\circ} 18^{\prime}$ to $25^{\circ} 45^{\prime}$ latitude North \& $84^{\circ} 20^{\prime}$ to $84^{\circ} 40^{\prime}$ longitude East. Its geographical area is $1624 \mathrm{~km}$. The total population of district is $10,87,676$ (Rural 9,96,855 Urban 90,821). The population density is 621 person $/ \mathrm{km}^{2}$ and sex ratio 899 females/1000 males. Buxar is also the most affected arsenic hit area especially the villages located near the river Ganga. Although, the Government funded works are being carried out in almost all the arsenic hit districts of Bihar but, still people are deprived of arsenic free drinking water and food, as this land area is highly fertile where crops of all types are extensively cultivated. Among all the villages of Buxar

*Corresponding author: Kumar A, Scientist-I, Research Centre, Mahavir Cancer Institute and Research Centre, Phulwarisharif, Patna - 801505 (Bihar) India, Tel: (0091) 9334740800, (0091) 06122250127 (O); E-mail: arunk31@rediffmail.com

Received March 16, 2015; Accepted April 25, 2015; Published April 28, 2015

Citation: Kumar A, Ali Md, Rahman S Md, lqubal A Md, Anand $G$, et al. (2015) Ground Water Arsenic Poisoning in "Tilak Rai Ka Hatta" Village of Buxar District, Bihar, India Causing Severe Health Hazards and Hormonal Imbalance. J Environ Anal Toxicol 5: 290. doi: 10.4172/2161-0525.1000290

Copyright: $\odot 2015$ Kumar A, et al. This is an open-access article distributed under the terms of the Creative Commons Attribution License, which permits unrestricted use, distribution, and reproduction in any medium, provided the original author and source are credited. 
Citation: Kumar A, Ali Md, Rahman S Md, Iqubal A Md, Anand G, et al. (2015) Ground Water Arsenic Poisoning in "Tilak Rai Ka Hatta" Village of Buxar District, Bihar, India Causing Severe Health Hazards and Hormonal Imbalance. J Environ Anal Toxicol 5: 290. doi: $10.4172 / 2161-0525.1000290$

Page 2 of 7

district, Tilak Rai Ka Hatta village in Simri block is the most severely affected area where no recent health related evaluation has been done in the population. Regular health related problems in the village was in the news has ignited the entire team to study this village.

\section{Materials and Methods}

\section{Location}

The study was done at Tilak Rai Ka Hatta village (a flood plain region) of Simri Block of Buxar district ( $\left.25^{\circ} 41^{\prime} 36^{\prime \prime} \mathrm{N}, 84^{\circ} 07^{\prime} 51^{\prime \prime} \mathrm{E}\right)$. The population of the village was approximately 5,348 in 2011 (Census, 2011 Interim report) [51]. There were approximately 340 households in 2011 (Census, 2011 Interim report). The village bears only a single Primary Health Centre and there is no availability of health check up related facilities for the villagers.

\section{Arsenic analysis and survey}

The water sample bottles ( $500 \mathrm{ml}$ polypropylene bottles) were well cleaned and pretreated with $1 / 10 \mathrm{~N}$ hydrochloric acid. 120 water samples were randomly collected in duplicate from hand pumps of the each households situated at every 50 metres of distance in the village and the depth of the handpumps were also recorded. After the collection, water samples were analyzed instantly by utilizing Merckoquant Arsenic Field test kit (Merck, Germany). For the final confirmation of the same, water samples were analysed using ThermoFisher U.V.Vis-Spectrophotometer following the SDDC (Silverdiethyledithiocarbamate) method against a blank at $520 \mathrm{~nm}$.

A survey in the entire village was conducted to estimate the per capita consumption of drinking water through hand pumps by the village people. For this, a questionnaire method was utilised and elderly, adults, youths and children of the village (1530 people) were interrogated related to consumption of drinking water from hand pumps, the depth of the hand pumps and their health related problems. The health related data were extensively collected to know the root cause of their health related problems. The blood samples of 120 village people were collected, where the arsenic contamination in hand pumps were very high. From blood, serum was separated for hormonal assessment of Testosterone, Estrogen and Thyroid hormones by their respective hormone kits. For determining the exact location of the hand pump, hand held global positioning system (GPS) receivers with an estimated accuracy of $\approx 10 \mathrm{~m}$ were utilised.

\section{Hormonal assessment}

Testosterone assay: Using the ELISA method Testosterone kit of AccuBind, Monobind, Lake Forest, CA, USA was utilized for the experiment. The normal range was calibrated and then $25 \mu \mathrm{l}$ serum samples were taken in the microwell plates. $100 \mu$ of enzyme conjugate was added in each well. After that, it was left for incubation at $37^{\circ} \mathrm{C}$ in incubator for 1 hour. Then, the wells were washed with $300 \mu$ distilled water for at least 3 times and blotted dry. Then, $100 \mu$ TMB solution was added as substrate in each well plate and was again left for the incubation for 15 minutes for the colour development. Finally, $100 \mu \mathrm{l}$ stop solution was added in each well to stop the reaction. Reading was taken at $630 \mathrm{~nm}$ through Merck ELISA reader in $\mathrm{ng} / \mathrm{ml}$ value.

Estrogen assay: Using the ELISA method Estradiol (E2) kit of AccuBind, Monobind, Lake Forest, CA, USA was utilized for the experiment. The normal range was calibrated and then $25 \mu \mathrm{l}$ serum samples were taken in the microwell plates. $50 \mu$ of Estradiol Biotin reagent was added into each well. After that, it was left for incubation at $37^{\circ} \mathrm{C}$ inside incubator for $30 \mathrm{~min} .50 \mu \mathrm{l}$ of Estradiol Enzyme reagent was added in each well. Then it was left for incubation at $37^{\circ} \mathrm{C}$ inside incubator for $90 \mathrm{~min}$. Then, the wells were washed with $300 \mu$ distilled water for at least 3 times and blotted dry. Then, $100 \mu$ substrate solution was added in each well plate and was again left for the incubation for 20 minutes for the colour development. Finally, $50 \mu \mathrm{l}$ stop solution was added in each well to stop the reaction. Reading was taken at $450 \mathrm{~nm}$ through Merck ELISA reader in $\mathrm{pg} / \mathrm{ml}$ value.

Thyroid stimulating hormone (TSH) assay: Using the ELISA method Thyrotropin (TSH) kit of AccuBind, Monobind, Lake Forest, CA, USA was utilized for the experiment. The normal range was calibrated and then $50 \mu \mathrm{l}$ serum samples were taken in the microwell plates. $100 \mu \mathrm{l}$ of TSH Enzyme reagent was added in each well. After that, it was left for incubation at $37^{\circ} \mathrm{C}$ inside incubator for $60 \mathrm{~min}$. Then, the wells were washed with $300 \mu \mathrm{l}$ distilled water for at least 3 times and blotted dry. Then, $100 \mu \mathrm{l}$ substrate solution was added in each well and was again left for the incubation for 15 minutes for the colour development. Finally, $50 \mu \mathrm{l}$ stop solution was added in each well to stop the reaction. Reading was taken at $450 \mathrm{~nm}$ through Merck ELISA reader in $\mu \mathrm{lU} / \mathrm{ml}$ value.

Statistical analysis: Data were analyzed with statistical software (Graphpad Prism 5) and values were expressed as Mean \pm SEM. Differences between the groups were statistically analyzed by one-way analysis of variance (ANOVA) using the Dunnet's test.

\section{Results}

\section{Ground water arsenic assessment in Tilak Rai Ka Hatta village}

The Tilak Rai Ka Hatta is situated near the vicinity of the river Ganga and is the flood plain region of the river (Figure 1). The analysis of 120 water samples from the entire village represented high prevalence of arsenic contamination in ground water as the entire region showed very unique pattern of arsenic contamination in ground water (Figures 2 and 3 ). The average depth levels of the hand pumps was between 60 to 100 feets (Figure 4) and the arsenic contamination in hand pumps was also highly prevalent in these depths only.

\section{Health Assessment}

The west region of the village showed high concentration of arsenic in the ground water. The severity of the health related problems was so high that the prevalence of common symptoms of arsenicosis were widely observed in the population of the village. The male and the females showed typical arsenicosis symptoms as hyperkeratosis in their palms as well as in their soles. The severe skin pigmentation that is melanosis in palm and trunk was observed in this particular region (Figures 5,6\&7). The commonly observed health related problems in the context of population percentage was well evaluated in 1530 village people (Table 1 ). The percentage of skin related problems was hyperkeratosis in palm and sole $(28 \%)$, melanosis $(31 \%)$ while in gastrointestinal problems gastritis (86\%), liver related problems (57\%), loss of appetite (64\%) were observed. The reproductive health in the population was also hampered as male infertility (azoospermia) cases were reported in 9 males while, 6 females reported female infertility case. 137 (9\%) females had irregular menstrual cycle denotes the level of health related problems in them. 6 cancer cases were also observed, out of which 4 had died earlier while 2 are still suffering, but none of them tried to had treatment of their cancer in a cancer centre. The cancer cases reported were with Gall bladder - liver cancer and skin cancer cases. The Primary and Middle School children of the village were observed with the severe symptoms of arsenicosis, as hyperkeratosis in palm and sole in $10 \%(\mathrm{n}=250)$ of 
Citation: Kumar A, Ali Md, Rahman S Md, Iqubal A Md, Anand G, et al. (2015) Ground Water Arsenic Poisoning in "Tilak Rai Ka Hatta" Village of Buxar District, Bihar, India Causing Severe Health Hazards and Hormonal Imbalance. J Environ Anal Toxicol 5: 290. doi: 10.4172/2161-0525.1000290

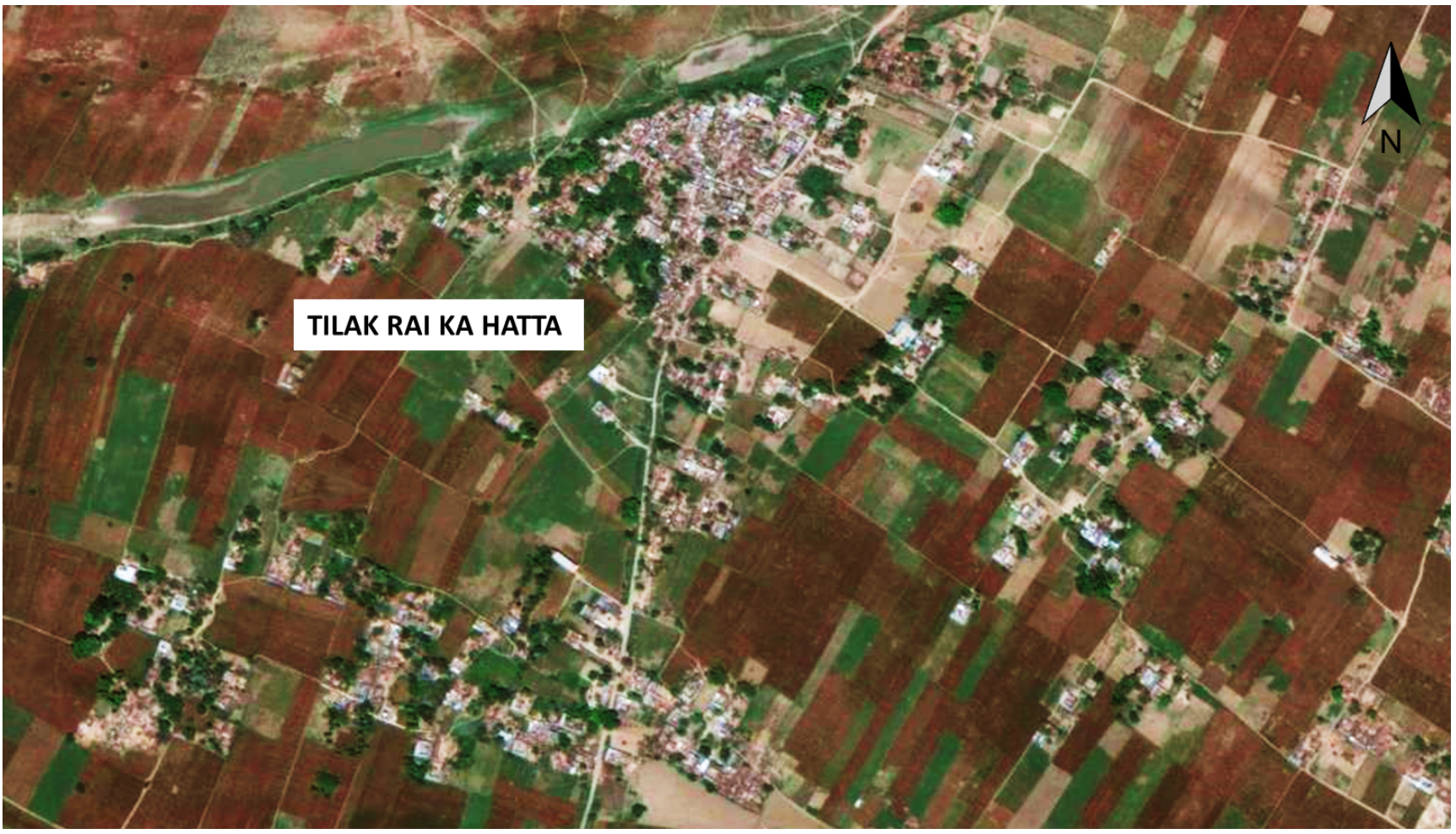

Figure 1: Geographical location of Tilak Rai Ka Hatta.

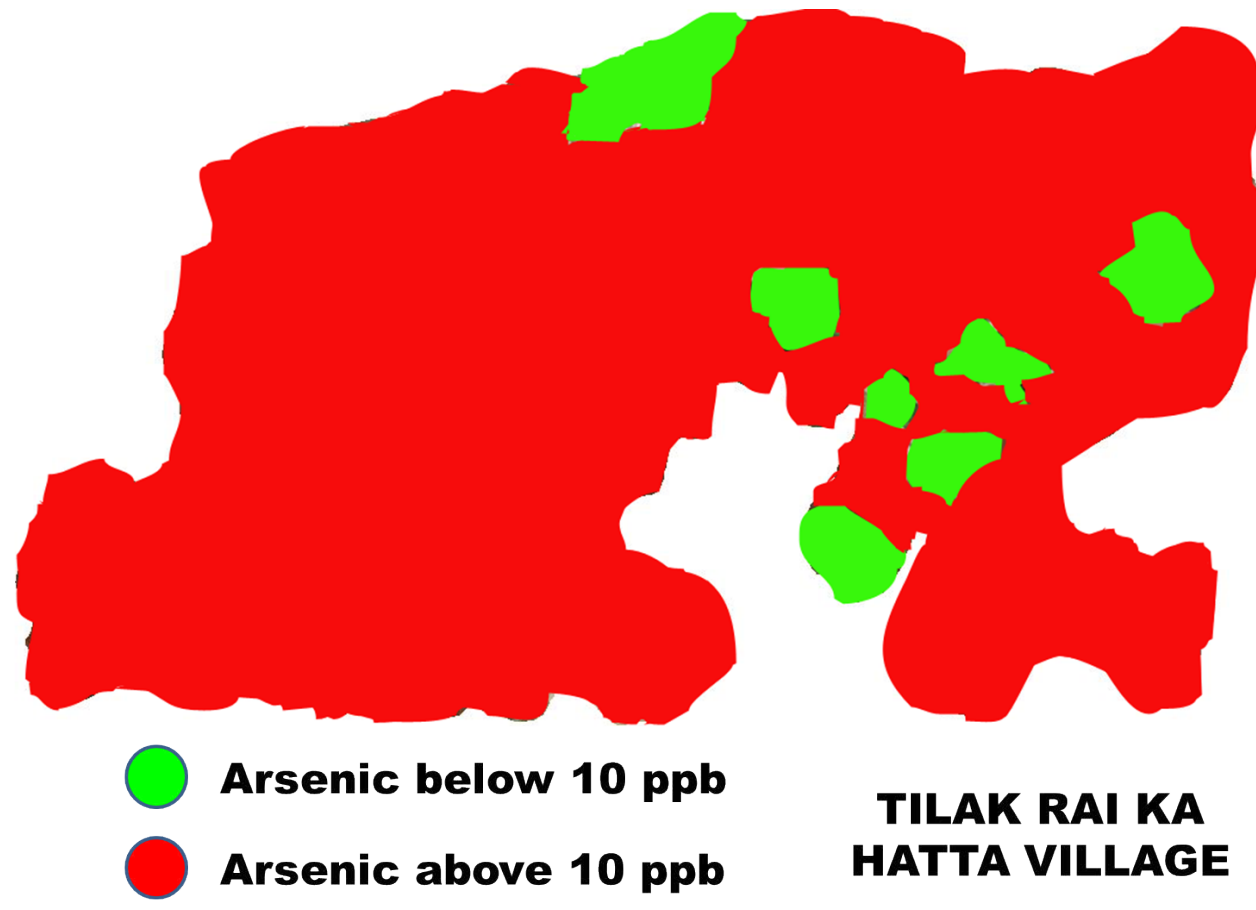

Figure 2: Ground water arsenic assessment in Tilak Rai Ka Hatta village.

the children and they were bound to drink arsenic contaminated water from the hand pumps in which the Arsenic concentration was more than $100 \mathrm{ppb}$.

\section{Hormonal Assessment}

The hormonal assessment showed declination in the serum testosterone levels. The most fascinating result was that out of $36.6 \%$ 
Citation: Kumar A, Ali Md, Rahman S Md, Iqubal A Md, Anand G, et al. (2015) Ground Water Arsenic Poisoning in "Tilak Rai Ka Hatta" Village of Buxar District, Bihar, India Causing Severe Health Hazards and Hormonal Imbalance. J Environ Anal Toxicol 5: 290. doi: 10.4172/2161-0525.1000290

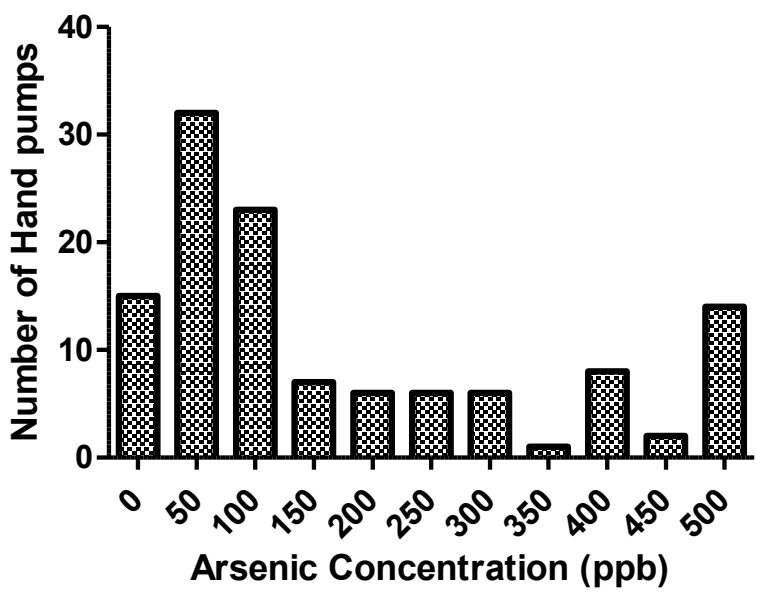

Figure 3: Arsenic level in Ground water of village Tilak Rai ka Hatta.

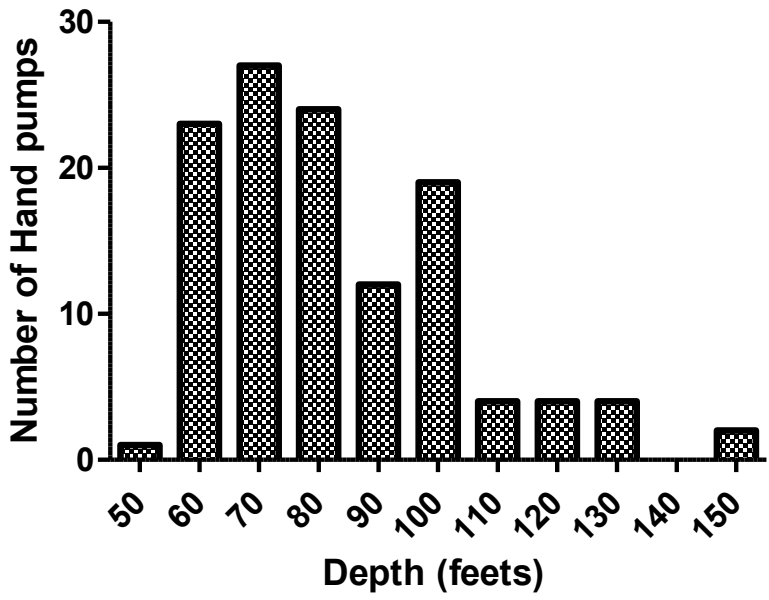

Figure 4: Depth of handpumps in village Tilak Rai ka Hatta.
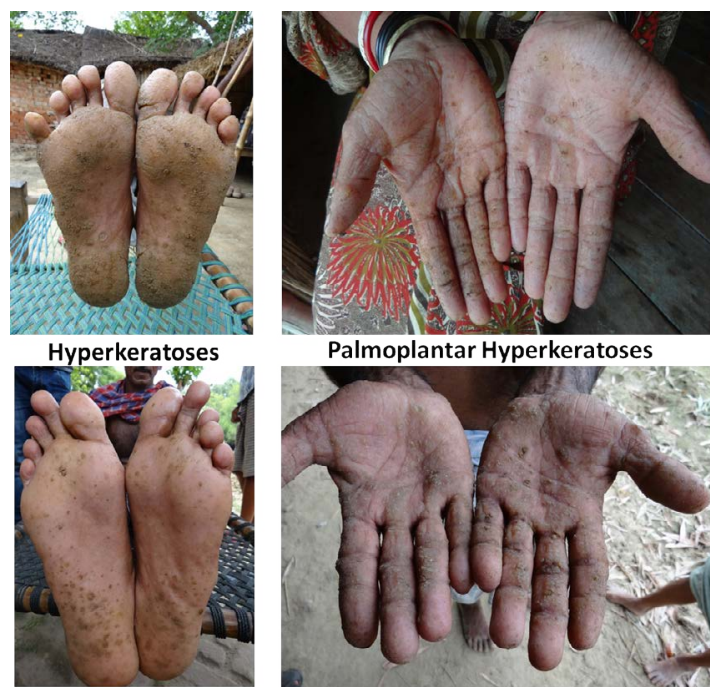

Palmoplantar Hyperkeratoses

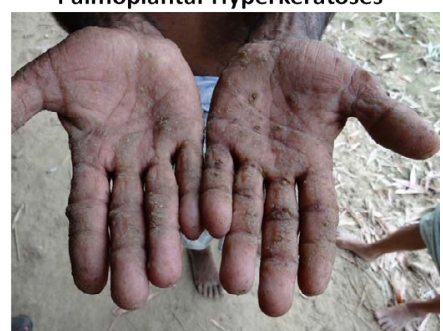

Figure 5: Symptoms of arsenicosis

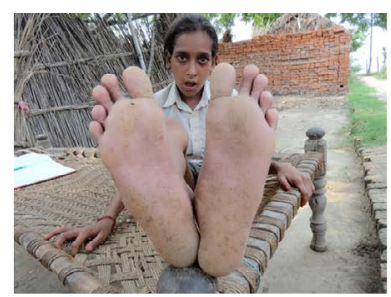

Hyperkeratoses in a 12 yr Old Gir

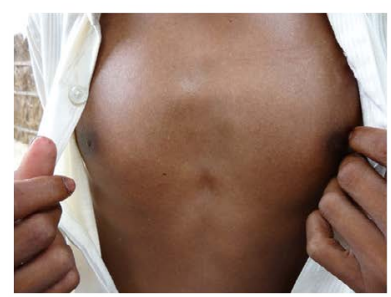

Melanosis in a 13 yr Old boy

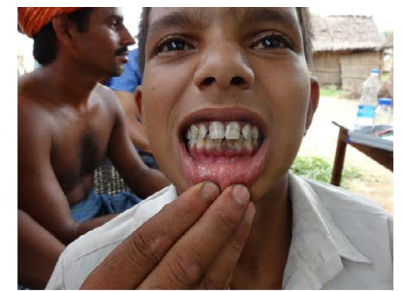

Dental Problem in a 12 Yr Old Boy

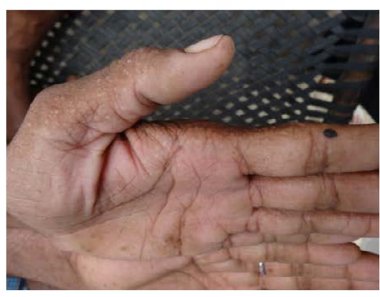

Melanosis in 15 yr Old boy
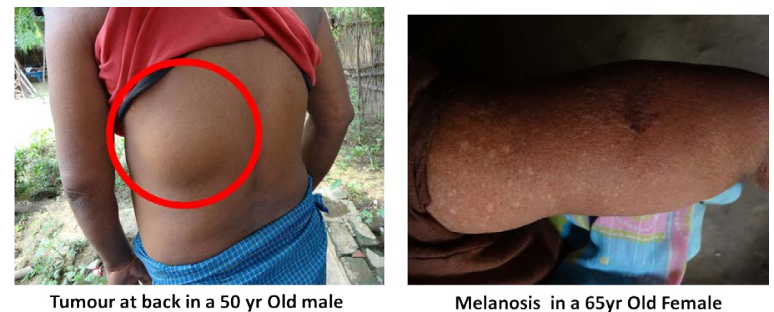

Tumour at back in a 50 yr Old male
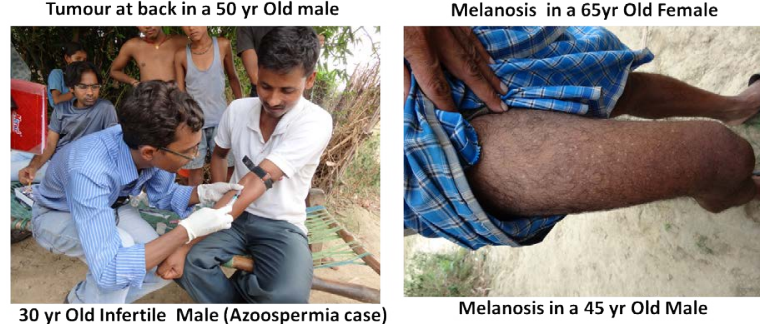

Figure 7: Health assessment.

$(\mathrm{n}=30)$ cases showed severe male infertility as their testosterone values were below $2.0 \mathrm{ng} / \mathrm{ml}$. 2 male subjects also showed the testosterone levels below $0.5 \mathrm{ng} / \mathrm{ml}$ (Figure 8). Similarly, in females blood samples collected in their premenopausal phase of their menstrual cycle reported $[100 \%(n=20)]$ menstrual problems and same females also exhibited symptoms of arsenicosis on their palm and sole (Figure 9). The thyroid abnormality was common in village people as it was well observed in population $48.14 \%(n=54)$ which exhibited elevated TSH levels (Figure 10)

\section{Discussion}

In the recent times, arsenic has led to severe health hazards in the Indian population. Although, the first case of arsenicosis was observed in West Bengal in 1980's $[16,18]$. The arsenic concentration in ground water had caused severe health related problems in the lower Ganga plains and since 2001 in the lower middle Ganga plain area melanosis, leucomelanosis, keratosis, hyperkeratosis, dorsum, non- petting 
Citation: Kumar A, Ali Md, Rahman S Md, Iqubal A Md, Anand G, et al. (2015) Ground Water Arsenic Poisoning in "Tilak Rai Ka Hatta" Village of Buxar District, Bihar, India Causing Severe Health Hazards and Hormonal Imbalance. J Environ Anal Toxicol 5: 290. doi: $10.4172 / 2161-0525.1000290$

oedema, gangrene, skin cancer and skin lesions in sole and palm have also been reported due to Arsenic contaminated drinking water [4,1215]. Presently, 16 districts of Bihar are affected with arsenic poisoning in ground water which has caused severe health related problems in the population [6].

In the present study, the flood plain Diara land area of river Ganga Tilak Rai Ka Hatta village showed high contamination of arsenic poisoning in hand pumps. The most fascinating results showed that $80 \%$ of the hand pumps of this village are affected with arsenic poisoning. In the population of 5,348, most of the villagers exhibited the typical symptoms of arsenicosis like hyperkeratosis, melanosis in palm and sole, skin irritation, anaemia, gastritis, constipation, loss of appetite, lungs problem etc.

\begin{tabular}{|c|c|c|c|c|}
\hline Symptoms & $\begin{array}{l}\text { Problems } \\
\text { Present in the } \\
\text { population }\end{array}$ & \begin{tabular}{|c} 
No \\
Problems \\
observed
\end{tabular} & $\begin{array}{l}\text { Total } \\
\text { Cases }\end{array}$ & P Value \\
\hline $\begin{array}{l}\text { Hyperkeratosis in palm } \\
\text { and sole }\end{array}$ & $428(28 \%)$ & $1102(72 \%)$ & 1530 & $<0.0001$ \\
\hline $\begin{array}{l}\text { Melanosis in Palm and } \\
\text { trunk }\end{array}$ & $473(31 \%)$ & 1057 (69\%) & 1530 & $<0.0001$ \\
\hline $\begin{array}{l}\text { Other skin problem - } \\
\text { irritation }\end{array}$ & $351(23 \%)$ & $1179(77 \%)$ & 1530 & $<0.0001$ \\
\hline Anaemia & $872(57 \%)$ & $658(43 \%)$ & 1530 & $<0.0001$ \\
\hline Gastritis & $1315(86 \%)$ & $215(14 \%)$ & 1530 & $<0.0001$ \\
\hline Liver problem & $887(58 \%)$ & $643(42 \%)$ & 1530 & $<0.0001$ \\
\hline Constipation & $596(39 \%)$ & $934(61 \%)$ & 1530 & $<0.0001$ \\
\hline Loss of appetite & $979(64 \%)$ & $551(36 \%)$ & 1530 & $<0.0001$ \\
\hline $\begin{array}{l}\text { Infertility in male and } \\
\text { female }\end{array}$ & $15(1 \%)$ & $1515(99 \%)$ & 1530 & $<0.0001$ \\
\hline Irregular Menstrual Cycle & $137(9 \%)$ & 1397 (91\%) & 1530 & $<0.0001$ \\
\hline Asthma or lung problem & $45(3 \%)$ & $1485(97 \%)$ & 1530 & $<0.0001$ \\
\hline Cancer cases & $6(0.4 \%)$ & $\begin{array}{c}1524 \\
(99.6 \%)\end{array}$ & 1530 & $<0.0001$ \\
\hline
\end{tabular}

Table 1: Showing Arsenic caused common symptoms and their percentage in the village population of 1530

\section{Testosterone Levels}

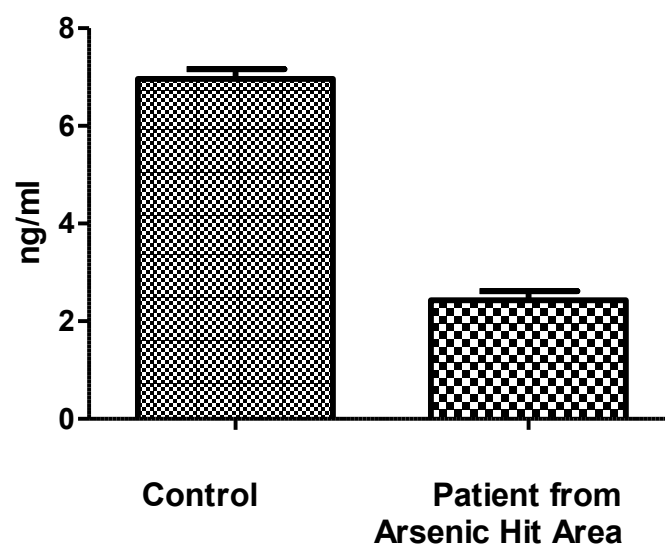

Figure 8: Levels of Testosterone in male persons of village Tilak Rai ka Hatta

\section{Estrogen levels}

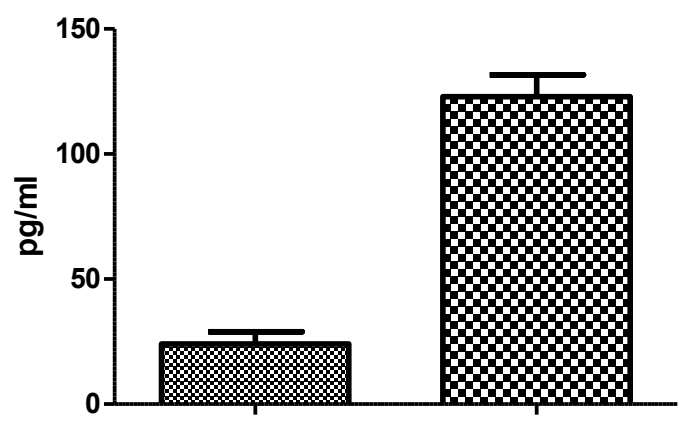

Control

Patient from Arsenic Hit Area

Figure 9: Levels of Estrogen in female persons of village Tilak Rai ka Hatta

\section{TSH Levels}

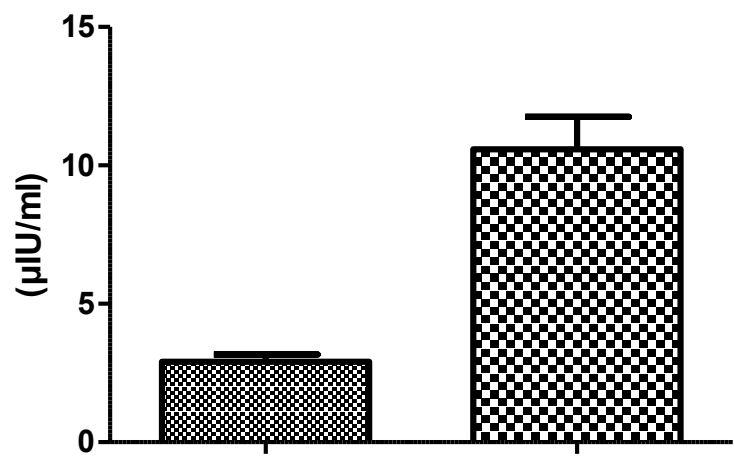

Control

Patient from Arsenic Hit Area

Figure 10: Levels of Thyroid Stimulating Hormone (TSH) in people of village Tilak Rai ka Hatta

The World Health Organisation (WHO) and the U.S. Environmental Protection Agency (EPA) have well recommended threshold of 10ppb for inorganic arsenic concentration in drinking water $[19,20]$.Unfortunately, millions of people are exposed to toxic levels of Arsenic and are at higher risk for the severe adverse health effects caused by it [21-24]. Although, cancer death risk is associated with daily consumption of 1.6 litres of water with inorganic arsenic (50ppb) has been estimated to be 21/1000 [25]. Arsenic has also been classified as Class I carcinogen by the International Agency of Research on Cancer (IARC) which means that there is sufficient evidence of its carcinogenicity to humans. Skin and several types of internal cancers, including, bladder, kidney, liver, gall bladder, lung and prostate have been found associated with arsenic ingestion [26-30].

In the present study cancer cases were also reported in few numbers 
Citation: Kumar A, Ali Md, Rahman S Md, Iqubal A Md, Anand G, et al. (2015) Ground Water Arsenic Poisoning in "Tilak Rai Ka Hatta" Village of Buxar District, Bihar, India Causing Severe Health Hazards and Hormonal Imbalance. J Environ Anal Toxicol 5: 290. doi: $10.4172 / 2161-0525.1000290$

Page 6 of 7

- skin cancer and Gall bladder cancer. The probability of these two types of cancer cases reported is due to ingestion of arsenic contaminated drinking water that is more than $300 \mathrm{ppb}$. The common reason for cancer cases is due to the carcinogenic effect of the transformed arsenic into Dimethyl Arseninous Acid (DMA). Furthermore, arsenic is not a direct acting genotoxin or mutagen but elevates the degree of DNA damage and mutations by altering DNA repair [30,31], or also acts as a co-carcinogen tumor promoter and progressor [32]. Increased generation of oxidative stress by reactive oxygen species (ROS) has led to oxidative signalling, altered cell signalling through other mechanisms, altered cell cycling and apoptotic and differentiation responses, and other mechanisms [33-43].

In this study, peculiar cases of male and female infertility was observed which was also confirmed by the hormonal assessment which showed declined levels of testosterone and elevated levels of estrogen hormones. The study is one of the unique studies ever done in the arsenic hit area of Buxar district of Bihar. It has been well reported that arsenic acts as a potent endocrine disruptor, altering gene regulation by the closely related steroid hormone receptors for glucocorticoids, mineralocorticoids, progesterone, and androgen in a similar manner $[44,45]$. Furthermore, in the presence of arsenic, the activated receptor is unable to stimulate the correct cascade of signals that usually results from hormone binding, particularly the ability to turn on certain hormone-responsive genes. Metals have not previously been shown to act as endocrine disrupters. Blocking the actions of the glucocorticoid receptor by arsenic in this unique way could explain, at least in part, many of the health effects observed in arsenic-exposed human populations [46-48].

The increased levels of thyroid stimulating hormones (TSH) in the population of the surveyed village are directly correlated with the ingestion of arsenic contaminated drinking water. The population showed clear symptoms of hyperthyroidism as their serum TSH levels were elevated. No proper mechanism has been deciphered till date with arsenic and TSH level elevations. But, a recent study has correlated the similar study [49]. The elevated levels of oestrogen and TSH increase the risk of female infertility due to the failure of ovulation [50].

This, unique study is the first ever study done in this huge population in the severe arsenic hit area of Buxar district. Thus, the present study concludes that, arsenic poisoning in entire village has caused severe health hazards to the village population. It is not only causing skin diseases or cancer but the entire population also has threat over the infertility. So, a proper strategy is immediately required to cater the severity of the arsenic poisoning in this village.

\section{Disclosure of interest} article.

The authors declare that they have no conflicts of interest concerning this

Funding: Department of Science and Technology (DST), TDT-SSTP Division, New Delhi, India (Government of India). Research Project No. DST/SSTP/ Bihar/155/2011 (G).

\section{Acknowledgement}

The authors extend their appreciation to the Department of Science and Technology, (SSTP Division) Ministry of Science and Technology, Government of India, New Delhi for the financial assistance of this work and to the institute for the entire infrastructural facilities.

\section{References}

1. Acharyya SK, Chakraborty P, Lahiri S, Raymahashay BC, Guha S, et al. (1999) Arsenic poisoning in the Ganges delta. Nature 401: 545.
2. Antman $\mathrm{KH}$ (2001) Introduction: the history of arsenic trioxide in cancer therapy. Oncologist 6 Suppl 2: 1-2.

3. Das D, Samanta G, Mandal BK, Roy Chowdhury T, Chanda CR, et al. (1996) Arsenic in groundwater in six districts of West Bengal, India. Environ Geochem Health 18: 5-15.

4. Chowdhury TR, Basu GK, Mandal BK, Biswas BK, Samanta G, et al. (1999) Arsenic poisoning in the Ganges delta. Nature 401: 545-546.

5. Chakraborti D, Basu GK, Biswas BK, Chowdhury UK, Rahman MM, et al (2001) Characterization of arsenic bearing sediments in Gangetic Delta of West Bengal-India. In: Chappell WR, Abernathy CO, Calderon RL (eds.) Arsenic Exposure and Health Effects. Elsevier Sciencem, New York, pp. 27-52.

6. Singh SK, Ghosh AK, Kumar A, Kislay K, Kumar C, et al. (2014) Groundwater Arsenic contamination and associated health risks in Bihar, India. Int J Environ Res 8: 49-60.

7. Ghosh AK, Singh SK, Bose N, Singh SK, Singh A, et al. (2007) Study of arsenic contamination in ground water of Bihar (India) along the River Ganges. International workshop on arsenic sourcing and mobilization in Holocene Deltas, Department of Science and Technology, pp. 83-87.

8. Ghosh AK, Singh SK, Bose N, Singh K (2009) Arsenic hot spots detected in the state of Bihar (India) a serious health hazards for estimated human population of 5.5 Lakh. In: Ramanathan AL, Bhattacharya P, Keshari AK, Bundschuh J, Chandrashekharam D et al. (eds.) Assessment of Ground Water Resources and Management. I. K. International Publishing House Pvt. Ltd., New Delhi, pp. $62-70$.

9. Saha D (2009) Arsenic groundwater contamination in parts of middle Ganga plain, Bihar. Current Science

97: 753-755

10. Haque R, Mazumder DN, Samanta S, Ghosh N, Kalman D, et al. (2003) Arsenic in drinking water and skin lesions: dose-response data from West Bengal, India. Epidemiology 14: 174-182.

11. UNICEF (1998) Plan of Action to Combat Situation Arising out of Arsenic Contamination in Drinking Water: Plan to Assist Government of West Bengal Report. United Nations Children's Fund, December.

12. [No authors listed] (2005) Study design and decision making in public health Proceedings of the 9th Biennial U.S. Centers for Disease Control/Agency for Toxic Substances and Disease Registry (CDC/ATSDR) Symposium on Statistical Methods. January 27-29, 2003. Atlanta, Georgia, USA. Stat Med 24: 491-669.

13. ATSDR/DTEM (2006) Agency for Toxic Substances and Disease Registry, Division of Toxicology and Environmental Medicine. ToxFAQs: CABSTM Chemical Agent Briefing Sheet Arsenic.

14. Karim M (2000) Arsenic in Groundwater and Health Problems in Bangladesh, Water Resources 34: 304-310.

15. Bagla P, Kaiser J (1996) India's spreading health crisis draws global arsenic experts. Science 274: 174-175.

16. Chakraborti D, Mukherjee SC, Pati S, Sengupta MK, Rahman MM, et al. (2003) Arsenic groundwater contamination in Middle Ganga Plain, Bihar, India: a future danger? Environ Health Perspect 111: 1194-1201.

17. Ahamed S, Kumar SM, Mukherjee A, Amir HM, Das B, et al (2006) Arsenic groundwater contamination and its health effects in the state of Uttar Pradesh (UP) in upper and middle Ganga plain, India: a severe danger. Sci Total Environ 370: $310-22$

18. Chakraborti D, Rahman MM, Paul K, Chowdhury UK, Sengupta MK, et al. (2002) Arsenic calamity in the Indian subcontinent What lessons have been learned? Talanta 58: 3-22.

9. Marshall G, Ferreccio C, Yuan Y, Bates MN, Steinmaus C, et al. (2007) Fiftyyear study of lung and bladder cancer mortality in Chile related to arsenic in drinking water. J Natl Cancer Inst 99: 920-928.

20. World Health Organization (WHO) (1993) WHO Guidelines for Drinking-Water Quality(3rdedn.) WHO, Geneva, Switzerland, pp. 515

21. Smith AH, Lingas EO, Rahman M (2000) Contamination of drinking-water by arsenic in Bangladesh: a public health emergency. Bull World Health Organ 78: 1093-1103. 
Citation: Kumar A, Ali Md, Rahman S Md, Iqubal A Md, Anand G, et al. (2015) Ground Water Arsenic Poisoning in "Tilak Rai Ka Hatta" Village of Buxar District, Bihar, India Causing Severe Health Hazards and Hormonal Imbalance. J Environ Anal Toxicol 5: 290. doi: $10.4172 / 2161-0525.1000290$

22. Nordstrom DK (2002) Public health. Worldwide occurrences of arsenic in ground water. Science 296: 2143-2145.

23. Gregori ID, Fuentes E, Rojas M, Pinochet H, Potin-Gautier M (2003) Monitoring of copper, arsenic and antimony levels in agricultural soils impacted and nonimpacted by mining activities, from three regions in Chile. $\mathrm{J}$ Environ Monit 5 : 287-295

24. International Agency for Cancer Research (IARC) (2004) Some drinking-water disinfectants and contaminants including arsenic. IARC Monographs on the Evaluation of Carcinogenic Risks to Humans, WHO, p. 84.

25. Bates MN, Smith AH, Hopenhayn-Rich C (1992) Arsenic ingestion and interna cancers: a review. Am J Epidemiol 135: 462-476.

26. Hopenhayn-Rich C, Biggs ML, Fuchs A, Bergoglio R, Tello EE, et al. (1996) Bladder cancer mortality associated with arsenic in drinking water in Argentina. Epidemiology 7: 117-124

27. Smith AH, Goycolea M, Haque R, Biggs ML (1998) Marked increase in bladder and lung cancer mortality in a region of Northern Chile due to arsenic in drinking water. Am J Epidemiol 147: 660-669.

28. Morales KH, Ryan L, Kuo TL, Wu MM, Chen CJ (2000) Risk of internal cancers from arsenic in drinking water. Environ Health Perspect 108: 655-661.

29. Ferreccio C, González C, Milosavjlevic V, Marshall G, Sancha AM, et al (2000) Lung cancer and arsenic concentrations in drinking water in Chile. Epidemiology 11: 673-679.

30. Andrew AS, Karagas MR, Hamilton JW (2003) Decreased DNA repair gene expression among individuals exposed to arsenic in United States drinking water. Int J Cancer 104: 263-268.

31. Andrew AS, Burgess JL, Meza MM, Demidenko E, Waugh MG, et al. (2006) Arsenic exposure is associated with decreased DNA repair in vitro and in individuals exposed to drinking water arsenic. Environ Health Perspect 114: 1193-1198.

32. Rossman TG (2003) Mechanism of arsenic carcinogenesis: an integrated approach. Mutat Res 533: 37-65.

33. Kitchin KT (2001) Recent advances in arsenic carcinogenesis: modes of action, animal model systems, and methylated arsenic metabolites. Toxicol Appl Pharmacol 172: 249-261.

34. Karagas MR, Stukel TA, Morris JS, Tosteson TD, Weiss JE, et al. (2001) Skin cancer risk in relation to toenail arsenic concentrations in a US populationbased case-control study. Am J Epidemiol 153: 559-565.

35. Karagas MR, Stukel TA, Tosteson TD (2002) Assessment of cancer risk and environmental levels of arsenic in New Hampshire. Int $\mathrm{J}$ Hyg Environ Health 205: 85-94.

36. Kessel M, Liu SX, Xu A, Santella R, Hei TK (2002) Arsenic induces oxidative DNA damage in mammalian cells. Mol Cell Biochem 234-235: 301-8.
37. Bode AM, Dong Z (2002) The paradox of arsenic: molecular mechanisms of cell transformation and chemotherapeutic effects. Crit Rev Oncol Hematol 42: 5-24.

38. Kitchin KT, Ahmad S (2003) Oxidative stress as a possible mode of action for arsenic carcinogenesis. Toxicol Lett 137: 3-13.

39. Shi H1, Shi X, Liu KJ (2004) Oxidative mechanism of arsenic toxicity and carcinogenesis. Mol Cell Biochem 255: 67-78.

40. Wasserman GA, Liu X, Parvez F, Ahsan H, Factor-Litvak P, et al. (2004) Wate arsenic exposure and children's intellectual function in Araihazar, Bangladesh [erratum appears in Environ. Health Perspect. 2004; 112(17): A980]. Environ Health Perspect 112: 1329-1333.

41. Lantz RC, Hays AM (2006) Role of oxidative stress in arsenic-induced toxicity Drug Metab Rev 38: 791-804.

42. Valko M, Rhodes CJ, Moncol J, Izakovic M, Mazur M (2006) Free radicals, metals and antioxidants in oxidative stress-induced cancer. Chem Biol Interact 160: $1-40$.

43. Aposhian HV, Aposhian MM (2006) Arsenic toxicology: five questions. Chem Res Toxicol 19: 1-15.

44. Bodwell JE, Kingsley LA, Hamilton JW (2004) Arsenic at very low concentrations alters glucocorticoid receptor (GR) mediated gene activation but not GR mediated gene repression: Complex dose-response effects are closely correlated with levels of activated GR and require a functional GR DNA binding domain. Chem. Res Toxicol 17: 1064-1076.

45. Bodwell JE, Gosse JA, Nomikos AP, Hamilton JW (2006) Arsenic disruption of steroid receptor gene activation: Complex dose-response effects are shared by several steroid receptors. Chem Res Toxicol 19: 1619-1629.

46. Kaltreider RC, Davis AM, Lariviere JP, Hamilton JW (2001) Arsenic alters the function of the glucocorticoid receptor as a transcription factor. Environ Health Perspect 109: 245-251.

47. Davey JC, Bodwell JE, Gosse JA, Hamilton JW (2007) Arsenic as an endocrine disruptor: effects of arsenic on estrogen receptor-mediated gene expression in vivo and in cell culture. Toxicol Sci 98: 75-86.

48. Georgescu B, Georgescu C, Daraban S, Bouaru A, Pascalau S (2011) Heavy Metals Acting as Endocrine Disrupters. Animal Science and Biotechnologies 44: 89-93

49. Ciarrocca M, Tomei F, Caciari T, Cetica C, Andrè JC et al. (2012) Exposure to arsenic in urban and rural areas and effects on thyroid hormones. Inhal Toxicol 24: $589-598$

50. Krassas GE (2000) Thyroid disease and female reproduction. Fertil Steril 74 $1063-1070$.

51. Census (2011) Interim Report of Population Census of India. 